\title{
Mammary gland development of dairy heifers fed diets containing increasing levels of metabolisable protein: metabolisable energy
}

\author{
Ronan L Albino ${ }^{1}$, Marcos I Marcondes ${ }^{1}$, Robert M Akers ${ }^{2}$, Edenio Detmann ${ }^{1}$, Bruno C Carvalho ${ }^{3}$ \\ and Tadeu E Silva ${ }^{3}$
}

${ }^{1}$ Animal Science Department, Federal University of Viçosa, Viçosa, Minas Gerais 36571-000, Brazil

${ }^{2}$ Department of Dairy Science, Virginia Polytechnic Institute and State University, Blacksburg 24061, USA

${ }^{3}$ Embrapa Gado de Leite, Juiz de Fora, Minas Gerais 36038-330, Brazil

Received 8 August 2014; accepted for publication 22 October 2014

\begin{abstract}
This study was conducted to evaluate the development of the mammary gland in Holstein heifers subjected to different dietary metabolisable protein (MP): metabolisable energy (ME) ratios. Twentyfive Holstein heifers (initial body weight (BW) $213 \pm 13 \cdot 5 \mathrm{~kg}$ and initial average age $7 \cdot 8 \pm 0 \cdot 5$ months) were divided into five treatments. The treatments were designed to provide MP: ME ratios equal to 33 , 38, 43, 48, and $53 \mathrm{~g}$ of MP per Mcal of ME. All diets were formulated to have the same energy content (2.6 Mcal ME/kg dry matter). Actual MP:ME ratios were $36 \cdot 2,40 \cdot 2,46 \cdot 2,47 \cdot 1$, and $50 \cdot 8 \mathrm{~g} \mathrm{MP} / \mathrm{Mcal}$ ME. The experiment was conducted in a randomised block design, while considering initial BW as a blocking factor to evaluate pre- and post-pubertal periods. Block effect was not observed for all variables evaluated; hence it was considered that the diets had the same influence both on pre- and post-pubertal phases. Dry matter and nutrient intake did not change between treatments, excepting protein intake and digestibility. Serum concentrations of insulin-like growth factor 1 increased linearly across treatments. Changes in the pixel brightness of mammary gland ultrasound images, which are associated with lipid content, were significantly influenced by MP:ME ratios in the diet of heifers that were subjected to accelerated growth rates. It is not recommended to use diets of less than $38 \mathrm{~g}$ MP/Mcal ME in diets to heifers allowed to gain more than $1 \mathrm{~kg} / \mathrm{d}$.
\end{abstract}

Keywords: Heifer, mammary gland, ultrasound.

Feeding to increase weight gain has been a common approach to reduce age at first calving and thereby reduce rearing costs. However, several authors have associated a greater rate of gain in the rearing phase with impaired mammary development and lower milk production at first lactation (Sejrsen \& Purup, 1997; Radcliff et al. 2000). On the other hand, others have suggested that an increased weight gain does not negatively impact mammary development when diets contain an adequate balance between energy and protein (Capuco et al. 1995; Dobos et al. 2000; Whitlock et al. 2002).

These conflicting results may be explained by the complex nutrition and physiology interactions that occur during the stage of life when these experiments are conducted (Sejrsen, 1994). Although mammary gland growth in the pre-pubertal phase is quantitatively less than in other stages (i.e. gestation), evidence suggests that the alterations that takes place in the mammary gland during both pre-pubertal and post-pubertal

*For correspondence; e-mail: ronan.albino@ufv.br period can have a strong influence on future milk production (Purup et al. 2000).

The mass of the mammary fat pad is probably directly related to the high weight gain during the pre-pubertal period. This in turn is directly related to the amount of energy consumed by the animal. However, some authors have suggested that the main influence on the accumulation of fat in the mammary gland is not specifically energy intake, but rather the proportion between the energy and the protein consumed by the animal (Capuco et al. 1995; Dobos et al. 2000).

Furthermore, some workers also have tested the influence of nutrition on post-pubertal heifers (Hoffman et al. 1996; MacDonald et al. 2005). According to these authors, the differences of diet energy throughout post-pubertal stage can change calving weight and consequently might influence mammary gland development and milk yield in the first lactation. Despite this fact, few studies have involved pre and post-pubertal heifers in the same experiment.

The focus of this experiment was to gain a better understanding of how feeding varying ratios of MP to ME 
Table 1. Composition and the content of the nutrients in the experimental diets

Metabolisable protein/Metabolisable energy in ration (g/Mcal)

\author{
Content of foods in the diet, g/kg DM \\ Corn silage \\ Soybean meal \\ Corn \\ Wheat bran
}

Minerals

33
$608 \cdot 0$
$141 \cdot 7$
$164 \cdot 9$
$77 \cdot 2$
$8 \cdot 2$

impacts heifer growth and mammary development using both pre-pubertal and post-pubertal heifers. Moreover, we chose to evaluate mammary development by using ultrasound technology. This non invasive approach allowed us to study development over time in the same animals and avoided complications such as mammary biopsies. The use of heifers at different ages was chosen to compare diet effects both in pre- and post-pubertal phases. Overall, we hypothesised that Holstein heifers with average daily gain (ADG) of $1.0 \mathrm{~kg} / \mathrm{d}$, and fed more than $43 \mathrm{~g}$ of metabolisable protein (MP) per Mcal of metabolisable energy (ME) would not have their mammary gland development affected.

\section{Material and methods}

\section{Experimental design}

The experiment was conducted at the Dairy Farm of Universidade Federal de Viçosa from December 2011 to April 2012, and it was divided into four 28-d periods. All procedures were previously approved by the Committee of Ethics and Animal Welfare of Universidade Federal de Viçosa, according to protocol no. 11/2012.

Twenty-five Holstein heifers with an average body weight (BW) of $213 \pm 13 \cdot 5 \mathrm{~kg}$ and an average initial age of $7 \cdot 8 \pm 0 \cdot 5$ months were distributed in a randomised block design with 5 replications, with initial weight as blocking factor. The heifers were kept in individual pens with a resting area, and provided with a feed and water trough. Heifers received the same diet from weaning until the beginning of experiment, being a total mixed ration formulated with corn silage, corn, soybean meal and minerals to gain daily $700 \mathrm{~g} / \mathrm{d}$ according to NRC (2001).

Before the start of the experiment, the heifers were allowed a 14-d adaptation period. Afterwards, they were allocated to their treatments $(n=5)$; each treatment varied the ratio between the dietary MP and ME as follows: 33, 38, 43, 48, and $53 \mathrm{~g}$ of MP/Mcal ME (Table 1).

Diets were formulated with a roughage: concentrate ratio of $60: 40$, thereby keeping the amount of energy fixed (2.6 Mcal ME/kg DM) while varying the amount of protein per treatment. All diets were formulated to provide a gain of $1 \mathrm{~kg} / \mathrm{d}$ based on the ME requirements of a heifer of $200 \mathrm{~kg}$ BW (NRC, 2001). The diets were supplied ad libitum daily, at $8 \cdot 00$ and $16 \cdot 00$.

The influence of treatments on the analysed variables will be based on the MP:ME ratios. However, the

\begin{tabular}{rrrr}
\multicolumn{1}{c}{38} & 43 & 48 & 53 \\
$608 \cdot 0$ & $600 \cdot 7$ & $599 \cdot 6$ & $600 \cdot 0$ \\
$181 \cdot 9$ & $243 \cdot 7$ & $260 \cdot 2$ & $298 \cdot 9$ \\
$146 \cdot 2$ & $108 \cdot 6$ & $93 \cdot 4$ & $63 \cdot 5$ \\
$60 \cdot 5$ & $41 \cdot 6$ & $41 \cdot 5$ & $32 \cdot 9$ \\
$3 \cdot 4$ & $5 \cdot 4$ & $5 \cdot 3$ & $4 \cdot 7$
\end{tabular}

protein:energy ratio will also be presented as CP:ME, since this ratio is commonly used by farmers.

During the last week of each experimental period, all heifers were weighed, body measurements recorded, blood collected, and mammary gland development evaluated via ultrasound. At the same time, the roughage and left-over feed from each animal were submitted to chemical analysis. In addition, at the end of the 1st and 3rd periods, digestibility trials were performed with all heifers.

\section{Mammary gland measurements}

Mammary gland development was evaluated with the help of an ultrasound device (B-mode) equipped with a micro-convex transducer, working at a frequency of $6 \mathrm{MHz}$ (DP2200, Mindray, China). Heifers at this stage of maturity have a relatively small mammary gland and so less tissue penetration is needed. Therefore, we chose to work at a $6-\mathrm{MHz}$ frequency, so as to prioritise the detail of the images. In all heifers from each period, the images were taken from all fore- and rear-quarters with a standardised probe position; the probe was placed at an angle of $45^{\circ}$ in relation to the teat base, always in the caudal-cranial direction as described by Nishimura et al. (2011). All procedures were performed with animals in a standing position without the use of sedatives (Fig. 1). Images from the four mammary gland quarters were taken from each animal in each period. These four values were averaged to compose the final value from each period.

Images were saved in bitmap (BMP) format and subsequently transferred to software Image $₫(\mathbb{N I H}$, Bethesda MD, USA). Within each image were outlined 6 random squares with 16 square $\mathrm{mm}$, being 3 squares taken about $1 \mathrm{~mm}$ away from the ductal structures and 3 squares taken about $4 \mathrm{~mm}$ away from ductal structures representing the ductal and sub ductal area, respectively (Fig. 2). The black circle marks the region in which the formation and growth of the ducts are most evident.

Within each of these defined squares, we used the pixels contained within each area to calculate the average pixel brightness. Specifically, in 8-bit images, each pixel was numerically represented on a scale of 256 thousand shades of grey $(0=$ black; $255000=$ white $)$ according to their brightness (Ferreira \& Rasband, 2011).

The amplitude or brightness of the pixels $(0-255000$ scale) can be defined in terms of echogenicity, i.e. how much a structure retains or reflects the sound wave from the 

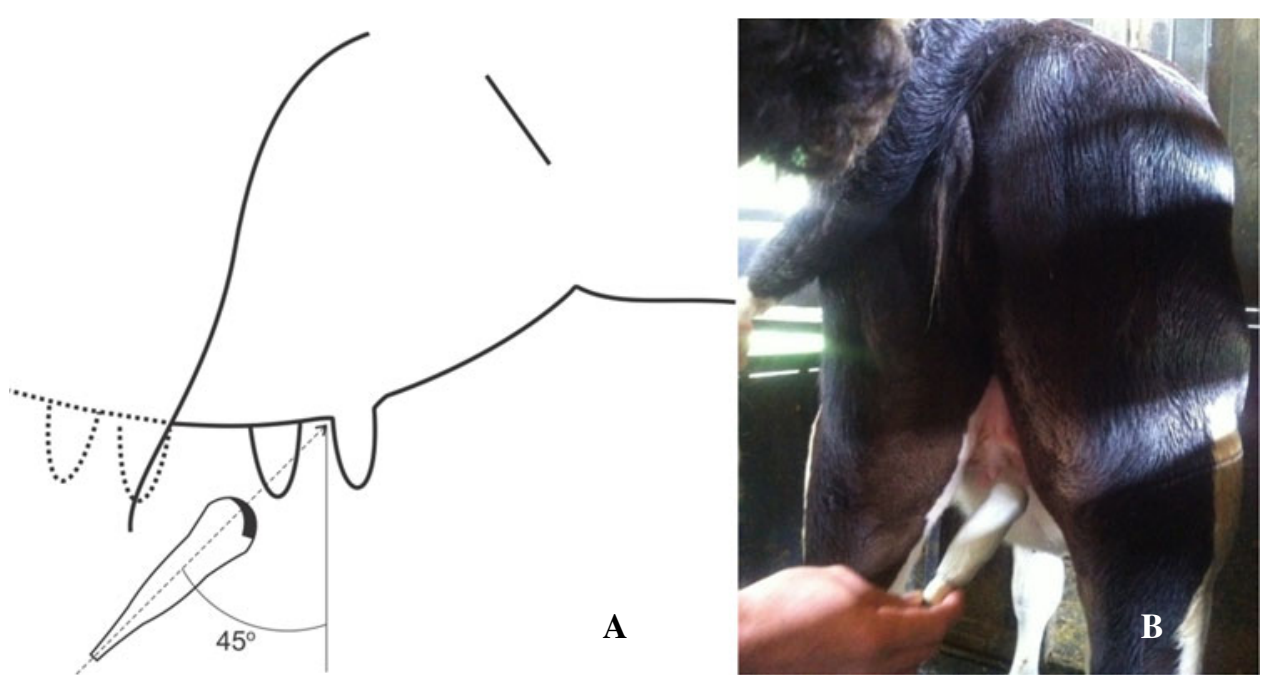

Fig. 1. Diagram representing the position of the probe during evaluation of mammary gland with ultrasound (a). Picture of a heifer where its mammary gland is being evaluated with ultrasound (b).

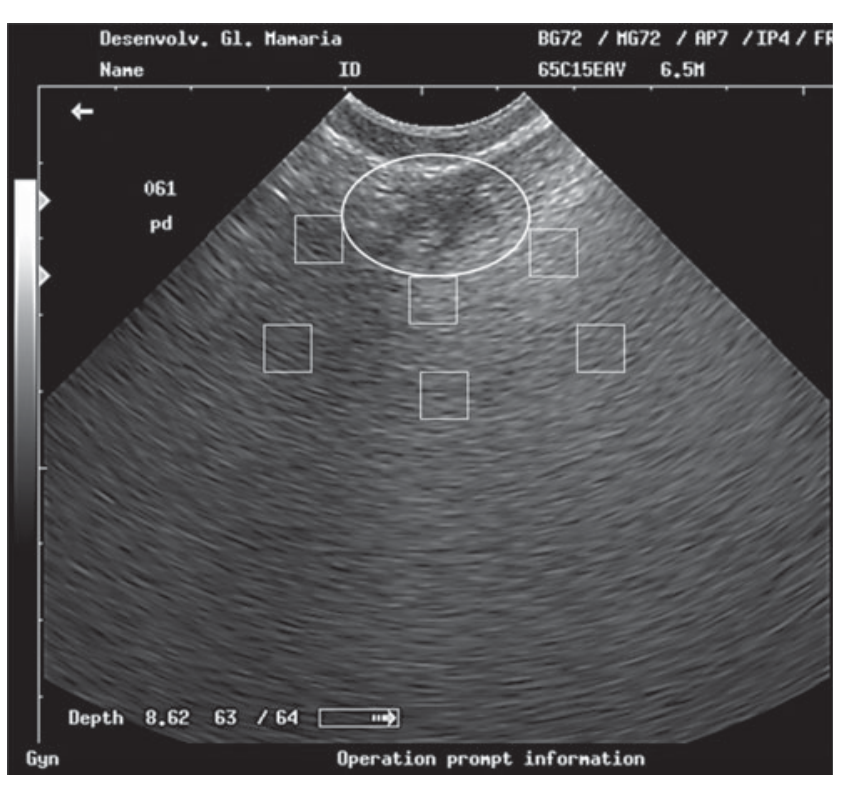

Fig. 2. Illustration of mammary gland ultrasound image opened up with the ImageJ software. The circle represents the buds growth. The upper squares are positioned close to the buds growth (ductal region) and the lower squares are positioned away to the buds growth (subductal region).

ultrasound transducer. Structures with a high ability to reflect sound waves (fat tissue) are hyperechoic and thus present with a higher pixel value. Conversely, tissues with a limited ability to reflect sound waves are hypoechoic and have a lower pixels value (parenchymal tissue).

\section{Blood sampling}

Blood samples were collected in the last week of each experimental period by jugular venipuncture, approximately
$4 \mathrm{~h}$ after the morning feeding. The blood was collected in $10-\mathrm{ml}$ tubes and immediately centrifuged at $1304 \mathrm{~g}$ for $15 \mathrm{~min}$ to obtain the blood serum. After that, three $1-\mathrm{ml}$ aliquots of serum were collected and frozen separately at $-20^{\circ} \mathrm{C}$. Subsequently, serum urea-nitrogen, glucose and IGF-1 values were obtained. Glucose analysis was performed according to the glucose oxidase method by using a kit supplied by Sigma (Sigma, St. Louis MO, USA) according to Sumner et al. (2007). Serum urea nitrogen was analysed according to the glutamate dehydrogenase method. IGF-1 was measured by the enzyme-linked immunosorbent assay (DSL-10-2800 ACTIVE IGF-1 ELISA of Diagnostic System Laboratories Inc., Webster TX, USA) immunoassay method. The coefficient of variation for IGF-1 usually varies $3 \cdot 6-8 \cdot 9$ and $3 \cdot 4-10 \cdot 9 \%$ for intra-assays and inter-assays, respectively.

\section{Digestibility trial}

Digestibility trials were conducted at the end of the first and third experimental periods. The digestibility values obtained in the first and third periods were extrapolated to the second and fourth periods, respectively. Thus, it was possible to estimate the digestible OM (DOM) intake and ME intake of each experimental period.

To estimate the amount of energy lost in faeces, a total faecal collection procedure was performed on all animals for 3 consecutive days. Animals remained loose within their pens and their faeces were collected from the floor, always avoiding any contamination with urine. At the end of each collection day, the total volume of faeces was weighed and sampled. Subsequently, the samples were dried in a ventilated oven at $55^{\circ} \mathrm{C}$ and a composite sample proportional to the quantity of excreted DM was formed.

To quantify the total nitrogen contents in the urine, urea nitrogen in the urine, allantoin, uric acid, and creatinine 
were evaluated using the spot urine collection technique over 3 consecutive days (Valadares et al. 1999). The first collection was performed before the morning feeding $(7 \cdot 30)$, the second between the 2 feedings (12.00), and the last after the 2 feedings (18.00).

At the end of the collection period, each sample of urine was divided into 2 sub-samples: one diluted sample and the other of pure urine. To compose the former, an aliquot of $10 \mathrm{ml}$ of urine was diluted into $40 \mathrm{ml} 0 \cdot 018 \mathrm{~m}-\mathrm{H}_{2} \mathrm{SO}_{4}$, so as to prevent bacterial destruction of the purine derivatives and precipitation of the uric acid. In the diluted-urine sample, analyses of allantoin were performed according to the technique described by Chen \& Gomes (1992).

Uric acid concentration was determined according to the method described by Fujihara et al. (1987). The urea content was determined according to the enzymic colourimetric method described by Kerscher \& Ziegenhorn (1985) and creatinine was determined by the endpoint method with the help of picrate and acidifier (Lagoa Santa, Minas Gerais, Brazil, Labtest Diagnóstica S.A). Urea-N in urine was calculated by multiplying the urea by a factor of 0.4667 . Daily creatinine excretion was estimated from the equation proposed by Chizzotti et al. (2008) for Holstein heifers, and the excretion of purine derivatives was calculated by summing the daily excretion of allantoin and the daily excretion of uric acid in the urine, and was expressed as $\mathrm{mmol} / \mathrm{d}$. Absorbed microbial purines $(\mathrm{mmol} / \mathrm{d})$ were calculated based on the excretion of purine derivatives (Prates et al. 2012) and the intestinal flow of microbial $N$ was calculated as a function of the absorbed purines using equations proposed by Prates et al. (2012).

\section{Analysis of the feedstuffs}

The corn silage and the left-overs from each animal were sampled during the last $7 \mathrm{~d}$ of each experimental period. At the end, a composite sample per animal of approximately $300 \mathrm{~g}$ was formed, on which all analyses were performed.

Composite samples of left-overs, faeces and roughage were pre-dried in a ventilated oven $\left(55^{\circ} \mathrm{C}\right)$, and were ground in a knife mill using a sieve with $1-\mathrm{mm}$ screen. All feedstuffs, left-overs and faeces were subjected to analysis of DM (method 934.01; AOAC, 1990), ash (method 924.05; AOAC, 1990), crude protein (method 920.87; AOAC, 1990), neutral detergent fibre (NDF) (Ankom-220 Fiber Analyzer, ANKOM Technology, USA) and ether extract (AOCS, 2004). Calculation of $\mathrm{ME}$ and MP were based on equations proposed by NRC (2001).

\section{Statistical analysis}

The experiment was conducted in a randomised block design, considering the initial weight as a factor of local control. The block was used to cover both stages prepubertal and postpubertal, so this effect could be tested in this trial. The evaluations were performed through a mixed model, in which treatments were considered fixed effects,
Table 2. Observed and predicted values for the percentage of metabolisable protein (MP) and metabolisable energy (ME) in the diet

Treatments (g MP/Mcal ME)

\begin{tabular}{lllll}
\hline 33 & 38 & 43 & 48 & 53
\end{tabular}

Predicted values based on feed tables

$\begin{array}{llllll}\text { Crude protein (CP), g/kg } & 136 \cdot 2 & 152 \cdot 4 & 167 \cdot 5 & 183 \cdot 1 & 198 \cdot 4\end{array}$

DM

$\begin{array}{lrrrrr}\text { MP, g/kg DM } & 85 \cdot 7 & 98 \cdot 6 & 110 \cdot 8 & 123 \cdot 4 & 135 \cdot 8 \\ \text { ME, Mcal/kg DM } & 2 \cdot 6 & 2 \cdot 6 & 2 \cdot 6 & 2 \cdot 6 & 2 \cdot 6 \\ \text { CP:ME, g/Mcal } & 52 \cdot 4 & 58 \cdot 6 & 64 \cdot 4 & 70 \cdot 4 & 76 \cdot 3 \\ \text { MP:ME ratio, g/Mcal } & 33 & 38 & 43 & 48 & 53 \\ \text { Obtained values by lab analysis } & & & & \\ \text { CP, g/ kg DM } & 146 \cdot 4 & 162 \cdot 5 & 186 \cdot 1 & 192 \cdot 5 & 209 \cdot 2 \\ \text { MP, g/kg DM } & 98 \cdot 1 & 112 \cdot 5 & 129 \cdot 4 & 134 \cdot 4 & 146 \cdot 7 \\ \text { ME, Mcal/kg DM } & 2 \cdot 7 & 2 \cdot 8 & 2 \cdot 8 & 2 \cdot 8 & 2 \cdot 8 \\ \text { CP:ME (g/Mcal) } & 54 \cdot 5 & 58 \cdot 8 & 67 \cdot 0 & 68 \cdot 8 & 73 \cdot 8 \\ \text { MP:ME ratio, g/Mcal } & 36.6 & 40 \cdot 7 & 46.6 & 48 \cdot 0 & 51 \cdot 8\end{array}$

and blocks considered random effects. The sum of the treatment square was orthogonally decomposed into linear and quadratic effects.

The pixel values derived from the analysis of ultrasound images did not follow a normal distribution and so a logarithmic transformation of the data was performed. However, the pixel data are illustrated in untransformed format to make it easier to view the data.

The mammary gland measurements from the different periods and the measurements of nutrient intake and digestibility throughout the experiment were included in the model as repeated measures. The structures of the (co) variance matrices were evaluated by corrected Akaike's information criterion (AIC). Compound symmetry heterogeneous autoregressive 1 or non-structured symmetry structures were used for the different variables. For all analyses, we adopted $P \leqslant 0.05$ as the significance level, and used PROC MIXED of SAS (Statistical Analysis System, version 9.2).

\section{Results and discussion}

Some of the CP:ME ratios established in this experiment are within the range of ratios proposed for heifers in the pre-pubertal phase (50-65 g CP:Mcal ME) by NRC (2001). However, some ratios $(68.8$ and 73.8$)$ were above the values recommended by the NRC (2001). A couple of authors have suggested that the protein levels recommended by the American system fall short of the requirements of Holstein heifers weighing above $200 \mathrm{~kg}$ (Valadares Filho \& Oliveira, 2010).

The MP:ME ratios observed at the end of the experiment $(36 \cdot 6,40 \cdot 7$, and $46 \cdot 6)$ did not coincide exactly with the predicted values $(33,38$, and 43$)$ as they were greater than expected (Table 2). This was probably related to the analysis of crude protein in the soybean meal (48.73 vs. $50 \cdot 39 \%$ 
Table 3. Average body weight, daily intake, and apparent total tract digestibility

\begin{tabular}{|c|c|c|c|c|c|c|c|c|c|c|}
\hline & \multicolumn{6}{|c|}{ MP:ME ratio (g/Mcal) } & \multicolumn{4}{|c|}{$P$ value } \\
\hline & 33 & 38 & 43 & 48 & 53 & SEM & $\mathrm{L}+$ & $\mathrm{Q} \neq$ & $\mathrm{P} \S$ & $\mathrm{T} \times \mathrm{Pq}$ \\
\hline $\begin{array}{l}\text { Body weight (BW), kg } \\
\text { Intake, } \mathrm{kg} / \mathrm{d}\end{array}$ & 283 & 285 & 270 & 288 & 285 & $20 \cdot 7$ & - & - & - & - \\
\hline DM & $7 \cdot 48$ & $7 \cdot 11$ & $7 \cdot 15$ & $7 \cdot 18$ & $7 \cdot 28$ & 0.907 & 0.61 & $0 \cdot 21$ & $<0.001$ & 0.99 \\
\hline Crude protein $(\mathrm{CP})$ & $1 \cdot 10$ & $1 \cdot 16$ & $1 \cdot 33$ & $1 \cdot 38$ & $1 \cdot 52$ & $0 \cdot 159$ & $<0.001$ & $0 \cdot 76$ & $<0.001$ & $0 \cdot 84$ \\
\hline Ether extract (EE) & $0 \cdot 16$ & $0 \cdot 15$ & $0 \cdot 14$ & $0 \cdot 14$ & $0 \cdot 14$ & $0 \cdot 017$ & $<0.001$ & $0 \cdot 13$ & $<0.001$ & 0.99 \\
\hline $\mathrm{NDF}_{\mathrm{om}(\mathrm{N})}++$ & $2 \cdot 66$ & $2 \cdot 50$ & $2 \cdot 51$ & $2 \cdot 54$ & $2 \cdot 56$ & $0 \cdot 320$ & $0 \cdot 47$ & $0 \cdot 13$ & $<0.001$ & 0.98 \\
\hline $\begin{array}{l}\text { Non-fibrous } \\
\text { carbohydrate }\end{array}$ & $3 \cdot 57$ & $3 \cdot 31$ & $3 \cdot 17$ & $3 \cdot 11$ & $3 \cdot 05$ & $0 \cdot 409$ & $<0.001$ & $0 \cdot 19$ & $<0.001$ & 0.99 \\
\hline $\begin{array}{l}\text { Digestible organic } \\
\text { matter }\end{array}$ & $5 \cdot 43$ & $5 \cdot 29$ & $5 \cdot 30$ & $5 \cdot 34$ & $5 \cdot 46$ & $0 \cdot 683$ & $0 \cdot 83$ & $0 \cdot 36$ & $<0.001$ & 0.99 \\
\hline $\begin{array}{l}\text { Metabolisable energy } \\
\text { Intake, } \mathrm{g} / \mathrm{kg} \mathrm{BW}\end{array}$ & $20 \cdot 1$ & $19 \cdot 6$ & $19 \cdot 9$ & $20 \cdot 1$ & $20 \cdot 6$ & $2 \cdot 55$ & $0 \cdot 41$ & $0 \cdot 39$ & $<0.001$ & 0.99 \\
\hline DM & $26 \cdot 5$ & $24 \cdot 9$ & $26 \cdot 5$ & $24 \cdot 9$ & $25 \cdot 6$ & $0 \cdot 322$ & $0 \cdot 43$ & $0 \cdot 66$ & $<0.001$ & 0.98 \\
\hline Neutral detergent fibre & $9 \cdot 4$ & $8 \cdot 8$ & $9 \cdot 3$ & $8 \cdot 8$ & $9 \cdot 0$ & $0 \cdot 113$ & $0 \cdot 32$ & $0 \cdot 48$ & $<0.001$ & 0.97 \\
\hline Apparent digestibility & & & & & & & & & & \\
\hline DM & $0 \cdot 73$ & $0 \cdot 75$ & 0.75 & $0 \cdot 75$ & $0 \cdot 76$ & $0 \cdot 010$ & 0.05 & $0 \cdot 37$ & $0 \cdot 36$ & $0 \cdot 81$ \\
\hline $\mathrm{CP}$ & 0.69 & $0 \cdot 72$ & $0 \cdot 75$ & $0 \cdot 77$ & 0.79 & $0 \cdot 012$ & $<0 \cdot 001$ & $0 \cdot 47$ & 0.90 & $0 \cdot 74$ \\
\hline $\mathrm{EE}$ & $0 \cdot 77$ & $0 \cdot 78$ & $0 \cdot 78$ & $0 \cdot 83$ & $0 \cdot 79$ & $0 \cdot 023$ & $0 \cdot 23$ & $0 \cdot 60$ & 0.07 & 0.93 \\
\hline $\mathrm{NDF}_{\mathrm{Om}(\mathrm{N})}$ & $0 \cdot 54$ & $0 \cdot 58$ & $0 \cdot 59$ & $0 \cdot 58$ & $0 \cdot 60$ & $0 \cdot 017$ & $<0.05$ & $0 \cdot 35$ & $<0.001$ & $0 \cdot 34$ \\
\hline $\begin{array}{l}\text { Non-fibrous } \\
\text { carbohydrate }\end{array}$ & $0 \cdot 87$ & $0 \cdot 87$ & $0 \cdot 86$ & $0 \cdot 86$ & $0 \cdot 86$ & 0.007 & $0 \cdot 20$ & $0 \cdot 30$ & $<0.001$ & $0 \cdot 83$ \\
\hline $\begin{array}{l}\text { † Linear effect } \\
\text { ₹Quadratic effect } \\
\text { § Period effect } \\
\text { ๆ Interaction between }\end{array}$ & & & & & & & & & & \\
\hline
\end{tabular}

DM), as our results revealed higher values than those used during the planning of the study.

The block analysis, utilised to measure differences between pre- and post-pubertal heifers, showed no difference $(P>0 \cdot 05)$ in any variables analysed in this trial. This highlights that MP:ME ratio on the diet had a similar effect between heifers of different stages of rearing, as suggested by others authors (Meyer et al. 2006).

There was no difference in the intakes of DM, NDF, ME or $\operatorname{DOM}(P>0.05)$ (Table 3$)$. Intake is regulated by both physical and chemotactic factors; while the latter have greater influence when the diets have a low filling capacity, the first is more related with diets with higher power to fill rumen (Fisher, 2002). The diets were formulated so as to contain the same amount of energy (2.6 Mcal ME/kg DM), to provide an ADG close to $1 \mathrm{~kg} / \mathrm{d}$, and they demonstrated an average of $73 \%$ DM digestibility. Therefore, it is suggested that intake was controlled according the level of energy in the diet, which in turn was similar.

MP:ME ratios affected $(P<0.05) \mathrm{CP}$ and non-fibrous carbohydrate (NFC) intakes (Table 3). These variables demonstrated an inverse linear behaviour, i.e. while the CP intake increased with the treatments, NFC intake decreased. This behaviour was brought about by an alteration in the proportion of the ingredients of the diet, where corn was replaced by soybean meal.
Results for the daily excretion of allantoin, uric acid, purine derivatives, nitrogen balance, microbial $\mathrm{CP}$, microbial efficiency and $\mathrm{N}$ in faeces were not affected by the treatment $(P>0 \cdot 05)$. However, the excretion of urea- $N$ in urine, total $\mathrm{N}$ in urine, $\mathrm{N}$ intake, the ratio between the microbial $N$ and $N$ intake, and serum urea- $N$ increased linearly $(P<0 \cdot 05)$ as MP: ME ratios increased (Table 4$)$.

Intestinal flow of microbial $N$, presented herein as MCP, was influenced by the ratio between the energy and $\mathrm{N}$ available in the rumen. $\mathrm{CP}$ intake had no influence on MCP, because the linear increase $(P<0 \cdot 05)$ in $C P$ intake did not affect $(P>0 \cdot 05)$ production of MCP. Thus, it is suggested that $\mathrm{MCP}$ was regulated by a factor other than $\mathrm{CP}$ intake such as the energy availability in the rumen, which is related to DOM intake, which was not different between treatments in this trial $(P=0 \cdot 830)$.

Synchronism between the energy and protein in the rumen was maximised in the treatment with the lower MP:ME ratios; after this level, the energy would limit the MCP synthesis. Some authors also suggest that the MCP synthesis is maximised when there is adequate synchronism between the protein and energy in the rumen (Aldrich et al. 1993; Dewhurst et al. 2000).

There was no difference $(P>0 \cdot 05)$ regarding the nitrogen balance and microbial efficiency (Table 3). The absence of effects on nitrogen balance is reinforced by the intake 
Table 4. Average excretion of allantoin, uric acid, purine derivatives (PD), urinary urea nitrogen, nitrogen balance, microbial crude protein $(\mathrm{CP})$, microbial efficiency, and serum urea nitrogen on the treatments

MP:ME ratio (g/Mcal)

Items

Allantoin, mmol/d

Uric acid, $\mathrm{mmol} / \mathrm{d}$

$\mathrm{PD}, \mathrm{mmol} / \mathrm{d}$

Micobial crude protein, g/d

Microbial efficiency, g/kg††

Microbial $\mathrm{N} / \mathrm{N}$ intake

$\mathrm{N}$ intake, g/d

$N$ in faeces, $g / d$

$\mathrm{N}$ in urine, $\mathrm{g} / \mathrm{d}$

Nitrogen balance, g/d

Urea-N in urine, $\mathrm{g} / \mathrm{d}$

Serum urea-N, mg/dl

+ Linear effect

¥Quadratic effect

$\S$ Period effect

I Interaction between treatment and period

t+g Microbial crude protein/kg digestible organic matter intake

\begin{tabular}{|c|c|c|c|c|c|c|c|c|c|}
\hline 33 & 38 & 43 & 48 & 53 & SEM & $\mathrm{L}+$ & $\mathrm{Q} \ddagger$ & $\mathrm{P} \S$ & $\mathrm{T} \times \mathrm{P} \boldsymbol{q}$ \\
\hline 146 & 134 & 1456 & 148 & 156 & $16 \cdot 3$ & $0 \cdot 28$ & $0 \cdot 40$ & $0 \cdot 17$ & 0.07 \\
\hline $15 \cdot 6$ & $13 \cdot 0$ & $13 \cdot 3$ & $14 \cdot 3$ & $15 \cdot 7$ & $2 \cdot 14$ & 0.78 & $0 \cdot 18$ & $<0.05$ & 0.53 \\
\hline 162 & 147 & 159 & 162 & 171 & $17 \cdot 9$ & $0 \cdot 30$ & $0 \cdot 31$ & $0 \cdot 11$ & $0 \cdot 15$ \\
\hline 571 & 500 & 559 & 567 & 605 & 65.9 & $0 \cdot 320$ & $0 \cdot 29$ & 0.32 & $0 \cdot 13$ \\
\hline 116 & 103 & 118 & 119 & 117 & $9 \cdot 7$ & 0.56 & $0 \cdot 86$ & 0.02 & $0 \cdot 38$ \\
\hline 0.58 & $0 \cdot 48$ & 0.47 & $0 \cdot 46$ & $0 \cdot 43$ & 0.037 & $<0.01$ & $0 \cdot 32$ & 0.03 & $0 \cdot 24$ \\
\hline 163 & 176. & 197 & 205 & 228 & $25 \cdot 1$ & $<0.01$ & $0 \cdot 83$ & $<0.01$ & 0.47 \\
\hline $57 \cdot 9$ & $53 \cdot 1$ & $56 \cdot 4$ & $54 \cdot 9$ & $56 \cdot 1$ & 6.96 & $0 \cdot 86$ & $0 \cdot 58$ & $0 \cdot 14$ & $0 \cdot 88$ \\
\hline $95 \cdot 6$ & 108 & 120 & 131 & 143 & $17 \cdot 7$ & $0 \cdot 001$ & $1 \cdot 00$ & $<0.01$ & 0.79 \\
\hline 9.94 & $15 \cdot 4$ & $21 \cdot 8$ & $25 \cdot 7$ & $28 \cdot 3$ & $10 \cdot 07$ & $0 \cdot 15$ & $0 \cdot 83$ & 0.09 & $0 \cdot 27$ \\
\hline $79 \cdot 5$ & $79 \cdot 7$ & 101 & 101 & 135 & $14 \cdot 74$ & $<0.01$ & $0 \cdot 17$ & $<0.01$ & $0 \cdot 49$ \\
\hline $11 \cdot 7$ & $12 \cdot 1$ & $14 \cdot 0$ & $13 \cdot 4$ & $16 \cdot 1$ & 0.78 & $<0.01$ & $0 \cdot 34$ & $<0.01$ & $0 \cdot 29$ \\
\hline
\end{tabular}

(Table 3) and performance data, which also did not show a significant difference $(P>0 \cdot 05)$.

Overall, MP:ME ratios did not affect $(P>0.05)$ the quantity of $N$ retained in the body of the animal, but increased $(P<0.05)$ the amount of $\mathrm{N}$ lost in the urine. This phenomenon would certainly be undesirable in current livestock systems, where farmers aim to increase performance at a low cost and with the lowest environmental impact. However, this conclusion is exclusively limited to this context, because the goals established in this study involve other aspects which will be addressed next.

The pattern of blood glucose concentration showed no differences $(P>0 \cdot 05)$ among the treatments. The mean value $(80 \cdot 2 \pm 1.90 \mathrm{mg} / \mathrm{dl})$ obtained in this experiment is similar to the 75 and $75.5 \mathrm{mg} / \mathrm{dl}$ found by Lalman et al. (1993) and Sumner et al. (2007), respectively.

On the other hand, the treatments had a linear effect $(P<0 \cdot 05)$ on the serum concentration of IGF-1 (Fig. 3a, b).

These results are similar to those obtained by Radcliff et al. (2004), who observed an increase in the concentration of IGF-1 in the serum of heifers fed with high protein and energy diets, and in heifers treated with bovine somatotropin. IGF-1 is a mitogenic hormone, i.e. it acts by stimulating cellular proliferation (Akers, 1990; Plath-Gabler et al. 2001). According to Berry et al. (2001), there is significant production of IGF-1 in the mammary gland of growing heifers. Purup et al. (2000) found a strong relationship $\left(R^{2}=0 \cdot 84\right)$ between the concentration of IGF-1 in the serum and IGF-1 in the mammary gland.

Thus, the analyses of IGF-1 obtained through the blood serum allow us to estimate the relative expected concentrations of IGF-1 in the mammary tissue. Consequently, heifers with the highest concentration of IGF-1 in the serum have high tissue concentration of IGF-I and may be more prone to mitogenic effects of IGF-1 on the mammary gland (Purup et al. 2000).

Treatments 33 and 38 increased linearly $(P<0 \cdot 05)$ the pixel brightness of the ultrasound images at the mammary gland on the ductal region (Fig. 4a). On the other hand, no effect was observed to other treatments under pixels brightness on the ductal region (Fig. 4a). The increased pixel values over the periods indicate that mammary gland of heifers under treatments 33 and 38 became more reflective of ultrasound waves. Therefore, the two lowest treatments may contribute to fat accumulation in the mammary gland of heifers reared under high performance.

The mammary gland is basically formed of parenchymal and stromal tissue. The secretory and ductular tissues in the mammary gland are epithelial tissues collectively referred to as parenchyma. The connective tissues that support the parenchyma are referred to as stroma, which contains cellular and noncellular (e.g. collagen, elastin) elements. Cells of stroma are primary fibroblasts and, depending upon stage of development, may contain a considerable number of adipocytes. During mammary gland development, the epithelial ducts grow into the surrounding stroma, which, from birth until late in first pregnancy, contains many adipocytes and is referred to as the mammary fat pad (Capuco \& Akers, 2010). Thus, as the mammary gland becomes fatter over the rearing period, the more the secretory tissue will penetrate the fat pad, diminishing the mammary gland development (Hovey et al. 1999).

The fat pad tissue is constituted by a matrix of connective and adipose tissue. When the fat tissue exhibits an exaggerated growth, such as when there is an imbalance between dietary protein and energy, this may create conditions that limit the future development of milk-secreting tissues (Hovey et al. 1999). According to VandeHaar (1997) and 

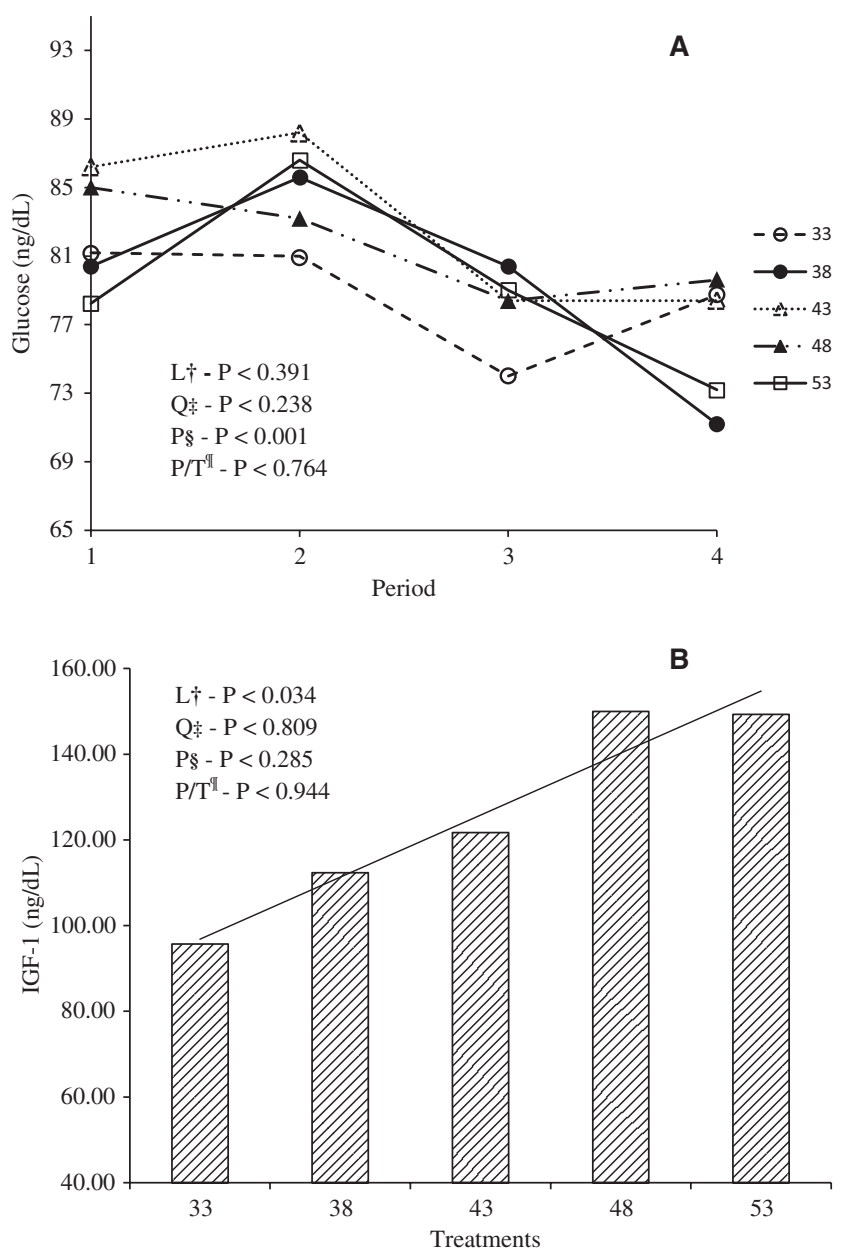

Fig. 3. Variation of the glucose on each treatment over the periods (a). Level of IGF-1 according with treatments (b). ' ${ }^{+}$Linear effects. ${ }^{\ddagger}$ Quadratic effects. ${ }^{\S}$ Period effect. " Interaction between treatment and period.

Whitlock et al. (2002), changes in the ratio of protein and energy would be responsible for large differences in tissue deposition in the gland.

In treatments 33, 38 and 43 the pixels brightness did not show any significant change ( $P>0 \cdot 05 ;$ Fig. $4 \mathrm{~b})$; therefore this region was not affected by diets at this time. Conversely, the pixels brightness in the treatments 48 and 53 decreased linearly over time $(P<0 \cdot 05)$.

The subductal region represents the fat pad region in the mammary gland. Mammary development occurs through growth of secretory tissue towards the fat pad. Thus, the reduction in pixels brightness may indicate that there was bigger growth of secretory tissue inside the fat pad of these treatments. We suggest that pixels reduction have been caused by an increase on secretory tissue (e. g. parenchymal tissue) because it has a lower power to reflect the sound waves, in turn it will produce lower pixels values. This result is linked to IGF-1 data (Fig. 3b), which increased $(P<0 \cdot 05)$ linearly between treatments, also reinforcing that there was a greater stimulus to growth of protein tissue (parenchymal
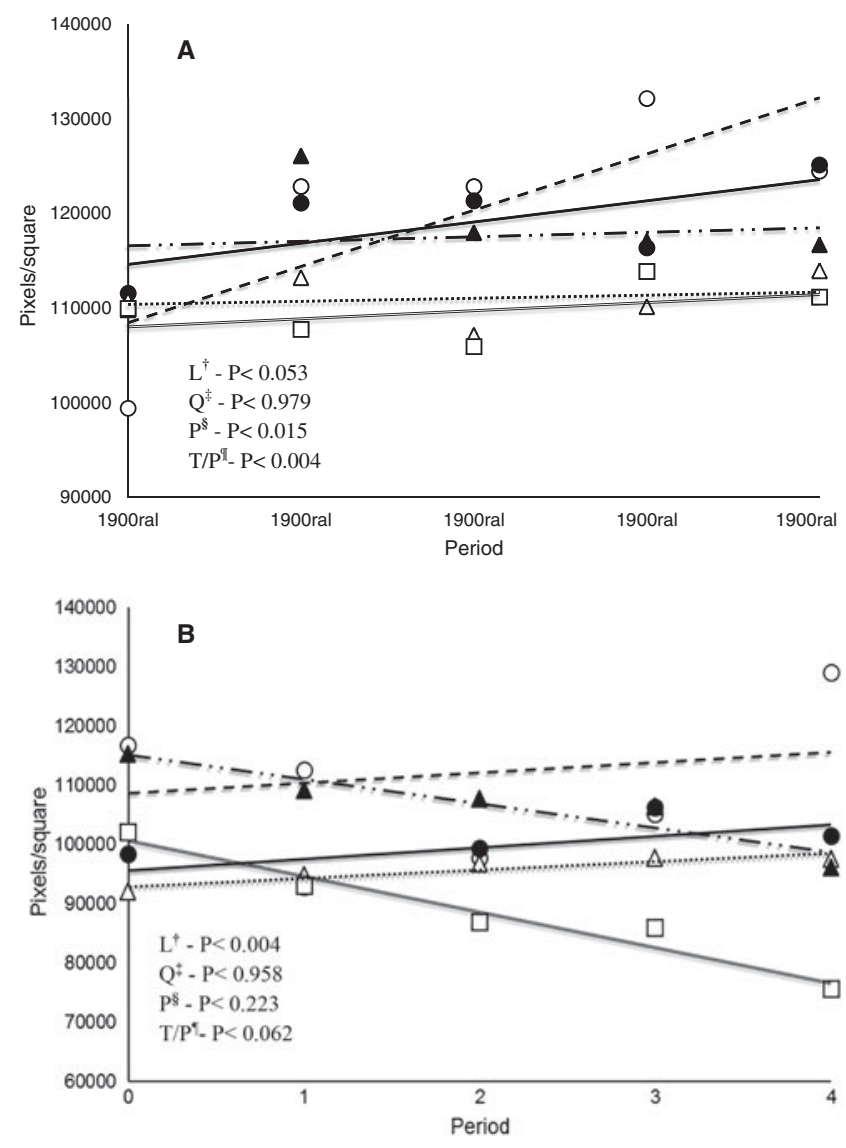

Fig. 4. Pattern of pixel values in the region ductal (a) and region subductal (b) over the evaluation period. The symbols represent:

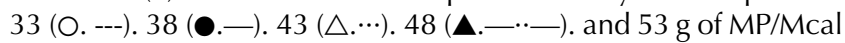
of ME ( $\square .=)$. ${ }^{\dagger}$ Linear effects. ${ }^{\ddagger}$ Quadratic effects. ${ }^{\S}$ Period effect. ${ }^{\top}$ Interaction between treatment and period.

tissue) over fat tissue in the fat pad region. Mechanisms related to the increase of parenchymal tissue as well as their differentiation will lead to an increase in milk production (Akers, 2000). So, in this trial, we found that protein: energy ratio unsuitable for heifers reared under high performance can be detrimental to mammary development.

\section{Conclusions}

The use of diets that contain MP:ME ratios less than $38 \mathrm{~g} / \mathrm{Mcal}$ might induce excess of fat accumulation in the parenchymal area of mammary gland, and therefore are not recommended when heifers are reared under high daily gains.

Refinements in ultrasound technology might allow a better estimation of the adipocyte concentration of the developing mammary gland relative to other stromal tissue elements. Certainly, significant changes in pixel values across periods suggest that ultrasound measurements can provide good measurements of tissue dynamics, especially within the developing mammary fat pad, independent of whether the heifers are pre- or postpubertal. 


\section{References}

Akers RM 1990 Lactation physiology: a ruminant animal perspective. Protoplasma 159 96-111

Akers RM 2000 Selection for milk production from a lactation biology viewpoint. Journal Dairy Science 5 1151-1158

Aldrich JML, Muller D, Varga GA \& Griel C Jr 1993 Nonstructural carbohydrate and protein effects on rumen fermentation nutrient flow and performance of dairy cows. Journal of Dairy Science 76 1091-1105

AOCS 2004 Official Methods and Recommended Practices of the American Oil Chemist's Society, 5th edition. Champaign, Urbana IL, USA: American Oil Chemists' Society

Association of Official Analytical Chemists (AOAC) 1990 Official Methods of Analyses of the AOAC, pp. 1-1230, 15 edition. Washington: Assoc OFF Agric Chemp

Berry SDK, Mcfadden B, Pearson RE \& Akers RM 2001 A local increase in the mammary IGF-1: IGFBP-3 ratio mediates the mammogenic effects of estrogen and growth hormone. Domestic Animal Endocrinology 21 39-53

Capuco AV, Smith JJ, Waldo DR \& Rexroad CE Jr 1995 Influence of prepubertal dietary regimen on mammary growth of Holstein heifers. Journal of Dairy Science 78 2709-2725

Capuco AV \& Akers RM 2010 Management and enviromental influences on mammary gland development and milk production. In Managing the Prenatal Environment to Enhance Livestock Productivity, Vol. XII (Ed. Springer Science + Business Media B. V.), Dordrecht.

Chen XB \& Gomes MJ 1992 Estimation of Microbial Protein Supply to Sheep and Cattle Based on Urinary Excretion of Purine Derivatives: an Overview of the Technical Details. Aberdeen, UK: International Feed Resources Unit Rowett Research Institute

Chizzotti ML, Valadares Filho SC, Valadares RFD, Chizzotti FHM \& Tedeschi LO 2008 Determination of creatinine excretion and evaluation of spot urine sampling in Holstein cattle. Livestock Science 113 218-225

Dewhurst RJ, Davies DR \& Merry RJ 2000 Microbial protein supply from the rumen. Animal Feed Science and Technology 85 1-21

Dobos RC, Nandra KS, Riley K, Fulkerson WJ, Lean IJ \& Kellaway RC 2000 The effect of dietary protein level during the pre-pubertal period of growth on mammary gland development and subsequent milk production in Friesian heifers. Livestock Production Science 63 235-243

Ferreira T \& Rasband WS 2011 "ImageJ User Guide - IJ 146" imagejnihgov/ ij/docs/guide

Fisher DS 2002 A review of a few key factors regulating voluntary feed intake in ruminants. Crop Science 42 1651-1655

Fujihara T, Ørskov ER, Reeds PJ \& Kyle DJ 1987 The effect of protein infusion on urinary excretion of purine derivatives in ruminants nourished by intragastric nutrition. Journal Agricultural Science 109 7-12

Hoffman PC, Brehm NM, Price SG \& Prill-Adams A 1996 Effect of accelerated postpubertal growth and early calving on lactation performance of primiparous holstein heifers. Journal Dairy Science $\mathbf{7 9} 11$

Hovey RC, McFadden TB \& Akers RM 1999 Regulation of mammary gland growth and morphogenesis by the mammary fat pad: a species comparison. Journal Mammary Gland Biology and Neoplasia 4 53-68

Kerscher L \& Ziegenhorn J 1985 Urea. In Methods of Enzymatic Analysis, Vol. 8, pp. 444-453 (Ed. HU Bergmeyer). Beach, FL: VCH Deerfield

Lalman DL, Petersen MK, Ansotegui RP, Tess MW, Clarck CK \& Wiley IS 1993 The effects of ruminally undegradable protein propionic acid and monensin on puberty and pregnancy in beef heifers. Journal of Animal Science 71 2843-2852

Macdonald KA, Penno JW, Bryant AM \& Roche JR 2005 Effect of feeding level pre- and post-puberty and body weight at first calving on growth, milk production, and fertility in grazing dairy cows. Journal of Dairy Science 88 3363-3375

Meyer MJ, Capuco AV, Ross DA, Lintault LM and Van Amburgh ME 2006 Developmental and nutritional regulation of the pre-pubertal heifer mammary gland: i parenchyma and fat pad mass and composition. Journal of Dairy Science 89 4289-4297

National Research Council 2001 Nutrient Requeriments of Dairy Cattle, Seventh revised edition. Washington, DC: National Academy Press, $381 \mathrm{p}$

Nishimura M, Yoshida T, El-Khodery S, Miyoshi M, Furuokam H, Yasuda J \& Miyahara K 2011 Ultrasound imaging of mammary glands in dairy heifers at different stages of growth. Journal of Veterinary Medical Science 73 19-24

Plath-Gabler A, Gabler C, Sinowatz F, Berisha B \& Schams S 2001 The expression of the IGF family and $\mathrm{GH}$ receptor in the bovine mammary gland. Journal Endocrinology 168 39-48

Prates LL, Valadares RFD, Valadares Filho SC, Detmann E, Santos SA, Braga JMS, Pellizzoni SG \& Barbosa KS 2012 Endogenous fraction and urinary recovery of purine derivatives in Nellore and Holstein heifers with abomasal purine infusion. Livestock Science 150 179-186

Purup SM, Vestergaard MS, Weber K, Akers RM \& Sejrsen K 2000 Local regulation of pubertal mammary growth in heifers. Journal of Animal Science 78 36-47

Radcliff RP, Vandehaar MJ, Chapin LT, Pilbeam TE, Beede DK, Stanisiewski EP \& Tucker HA 2000 Effects of diet and injection of bovine somatotropin on pre-pubertal growth and first-lactation milk yields of Holstein cows. Journal of Dairy Science 83 23-29

Radcliff RP, Vandehaar MJ, Kobayashi Y, Sharma BK, Tucker HA \& Lucy MC 2004 Effect of dietary energy and somatotropin on components of the somatotropic axis in holstein heifers. Journal of Dairy Science $\mathbf{8 7}$ 1229-1235

Sejrsen K 1994 Relationships between nutrition puberty and mammary development in cattle. Proceedings of the Nutrition Society 53 103-111

Sejrsen K \& Purup S 1997 Influence of pre-pubertal feeding level on milk yield potential of dairy heifers: a review. Journal of Animal Science $\mathbf{7 5}$ 828-835

Sumner J, Valdez MF \& Mcnamara JP 2007 Effects of chromium propionate on response to an intravenous glucose tolerance test in growing Holstein heifers. Journal Dairy Science 90 3467-3474

Valadares RFD, Broderick GA, Valadares Filho SC \& Clayton MK 1999 Effect of replacing alfalfa silage with high moisture corn on ruminal protein synthesis estimated from excretion of total purine derivatives. Jounal Dairy Science 82 2686-2696

Valadares Filho SC \& Oliveira AS 2010 Nitrogen compounds in dairy heifers diet. In [Dairy Heifers], Vol I. (Ed. Graphiti gráfica e editor Itda) Fortaleza, CE

VandeHaar MLJ 1997 Dietary protein and mammary development of heifers. Journal Dairy Science $\mathbf{8 0} 216$

Whitlock BK, Vandehaar MJ, Silva LFP \& Tucker HA 2002 Effect of dietary protein on pre-pubertal mammary development in rapidly growing dairy Heifers. Journal Dairy Science 85 1516-1525 